\section{RESISTANCE WELDING}

$\mathrm{W}$

HAT may seem at first sight unlikely subjects can often be treated by resistance welding by carefully anticipating the conditions. Each welding possibility must be considered on its merits and not crippled by attempts to improvise a solution from a standard machine not suited to the special requirements of the case, and the advice of manufacturers should be sought.

The Electrical Review of November 15 shows what can be done in this way in a description of the Metrovick "A S P" heavy-duty spot welder; this machine is flexible enough to deal with light work also, and can be adapted for projection welding by changing the eleetrodes, which are bolted to top and bottom platens, for contact blocks. A 12-in. diameter double-acting cylinder provides a maximum pressure between platens of 9,000 lb. from air supplied at $80 \mathrm{lb}$. per sq. in. from reservoirs built into the top of the frame. Within the frame is a $250 \mathrm{kva}$. welding transformer having a secondary winding consisting of copper tube of square section brazed into cast copper headers through which the cooling water circulates. The primary has five tappings and a series-parallel connexion, all taken to a double-unit tapping switch on the frame giving a wide range of welding currents.

For straightforward projection welding, a contactor and timing device for controlling the duration of the weld have been found quite satisfactory. For more involved work, espeeially spot welding of heavy sections, the interrupted eurrent method offers advantages. This method with 'woodpecker' control depends upon the employment of synchronous timing devices that allow instantaneous switching of heavy currents, as there is no inertia due to the moving parts, and permits the application of repeated and predetermined current impulses by a single operation. The use of interrupted current greatly lengthens the life of the electrodes when spot welding heavy sections, and so greater thickness of metal can be dealt with by any one machine. It is of advantage also on jobs that tend to 'flash' or blow out weld metal during the passage of the current. When spot welding thick pieces of steel together, the heat generated, combined with the high pressure applied to the electrode tips, tends to cause the material to anneal and the tips to 'mushroom' out and fuse to the steel. While the time between impulses allows the water flowing to the electrodes to control the temperature of their tips, the interval is insufficient for appreciable heat to be lost from the inside surfaces of the plates where the weld is being formed.

The control consists of an ignition panel for determining the welding current, and a small panel mounted on its side housing two thyratron-controlled relays for regulating the time at which set-up pressure is applied and the length of the forging period. The latter is the time of pressure 'dwell' after the weld is completed and before the electrodes are allowed to separate. A differential pressure is obtainable by electrically operated air valves, and the air can be exhausted underneath the piston at any desired stage of the cycle by means of the thyratron relay in order to apply a sudden pressure increase to the electrodes. This upset pressure is of considerable value in consolidating welds made in the thicker sheets and in obtaining a flush joint on projection welded assemblies.

\section{FORTHCOMING EVENTS}

\author{
Monday, December I6
}

Royal Geographical Society (at Kensington Gore, London, S.W.7), at 3 p.m.-Mr. E. A. Gunther: "Sierras of Venezuela".

\section{Tuesday, December I7}

Institution of Crvil Engineers (at Great George Street, London, S.W.1), at 1.30 p.m.-Mr. Alec George VaughanLee: "The Mohammad Aly Barrages, Ezypt."

North-EAst Coast Institution of Engineers AND SHIPBUILDERS (in the Literary and Philosophical Society's Lecture Theatre, Newcastle-upon-Tyne), at 6 p.m.-Sir Stephen J. Pigott : "The Engining of Highly Powered Ships" (Sir Charles Parsons Memorial Lecture).

\section{APPOINTMENTS VACANT}

APPLICATIONS are invited for the following appointments on or before the dates mentioned :

Lecturer in the Department of Physics and Applied Ph ygics of the Technical College, Cardiff-The Director of Education, City Hall, Cardiff (December 20).

Lectorer in Electrical Enginenring at the Constantine Technical College, Middlesbrough--The Director of Education, Education Offices, Woodlands Road, Middlesbrough (December 28).

\section{REPORTS AND OTHER PUBLICATIONS \\ (not included in the monthly Books Supplement)}

\section{Great Britain and Ireland}

Department of Scientiflc and Industrial Research. Report of the Fuel Research Board for the Year ended 31st March 1939, with Report of the Director of Fuel Research. Pp. iv +206 . (London: H.M. Stationery Office.) $38.6 d$. net.

\section{Other Countries}

Egyptian Government: Ministry of Public Works. Annual Report for the Year 1930-1931. Part 1. Pp. ix+163. (Cairo: Government
Press.) P.T.30. Press.) P.T.30 Research. Fisheries Circular No. 2: The Canning of Fish and Fish Products in Australia. By E. J. Ferguson Wood. Pp. 56. Pamphlet No. 100: Studies on the Marketing of Fresh Fish in Eastern Australia. Part 2: The Bacteriology of Spoilage of Marine Fish. By E. J. Ferguson Wood. Pp. 92. (Melbourne: Government Printer.) [511

Commonwealth of Australia: Council for Scientiffe and Industrial Research. Bulletin No. 133: A Soil Survey of the Mildura Irrigation Settlement, Victoria. By F. Penman, G. D. Hubble, J. K. Taylor
and P. D. Hooper. Pp. 76. (Melbourne : Government Printer.) [611 U.S. Office of Education: Federal Security Agency. Leaflet No. 28: Education in the Union of Soviet Socialist Republics and in Imperial Russia-Selected References. Compiled by Severin $\mathbf{K}$. Turosienski. Pp. ii +16 . (Washington, D.E.: Government Printing
[711

Proceedings of the United States National Museum. Vol. 89, No. 3093: Two New Anuran Amphibians from Mexico. By Edward $\mathbf{H}$. Printing Office.)

Proceedings of the United States National Museum. Vol 88 , No. Proceedings of the United states National Museum. Vol. 88, No. 3090 : Seven New Species and One New Genus of Hydroids, mostly from the Atlantic Coast. By C. McLean Fraser. Pp. 575-580 + plates
32-33. (Washington, D.C.: Government Printing Office.) [111] Field Museum of Natural History. Anthropological Series, vol. 27, No. 2: Notes on Skidi Pawnee Society. By George A. Dorsey and James R. Murie. Pp. 65-120. 40 cents. Botanical Series, Vol. 22 No. 3: Studies of American Plants, XI. By Paul C. Standley. Pp. 131-218. 50 cents. (Chicago: Field Museum of Natural History.) [1211 Publications of the Observatory of the University of Michigan. Vol. 8, No. 3: A Self-Recording Direct-Intensity Microphotometer. By Robley C. Williams. Pp. 45-56. (Ann Arbor, Mich.: University
of Michigan.)

Rubber Research Institute of Malaya. Annual Report, 1939. Pp 278. (Kuala Lumpur: Rubber Research Institute of Malaya.) dollar. Publications of the Dominion Observatory, Ottawa. Vol. 13 :
Bibliography of Seismology. No. 6: Items 4770-4868, April, May, June 1940. By Ernest A. Hodgson. Pp. 89-104. (Ottawa: King's
Printer.) 25 cents. Printer.) 25 cents.

U.S. Department of Agriculture. Farmers' Bulletin No. 1850 The Armyworm and its Control. By W. R. Walton and C. M. Packard. Pp. ii +12 . (Washington, D.C.: Government Printing Office.) 5 cents. 